\title{
Characteristics of Grade 2 Disability in Indonesian Children with Leprosy: A Five-Year Multicenter Retrospective Study
}

\author{
Hendra Gunawan, (ID) ${ }^{1-3}$ Atika \\ Kamilia, ${ }^{1,2}$ Sri Linuwih \\ Menaldi, (iD) ${ }^{2-4}$ Melani Marissa, 2,4 \\ Cita Rosita Sigit Prakoeswa, (iD ${ }^{2,3,5}$ \\ Medhi Denisa Alinda, ${ }^{2,5}$ Dhelya \\ Widasmara, 2,6 Santosa Basuki, ${ }^{2,6}$ \\ Qaira Anum, 2,7 Tutty Ariani, 2,7 \\ Enricco H Mamuaja, ${ }^{2,8}$ Luh Made \\ Mas Rusyati ${ }^{2,9}$
}

'Department of Dermatology and Venereology, Faculty of Medicine,

Universitas Padjadjaran, Hasan Sadikin Hospital, Bandung, Indonesia; ${ }^{2}$ Indonesian Leprosy Study Group - Indonesian Society of Dermatology and Venereology, Jakarta, Indonesia; ${ }^{3}$ ndonesian College of Dermatology and Venereology, Jakarta, Indonesia; ${ }^{4}$ Department of Dermatology and Venereology, Faculty of Medicine,

Universitas Indonesia, Cipto Mangunkusumo Hospital, Jakarta, Indonesia; ${ }^{5}$ Department of Dermatology and Venereology, Faculty of Medicine, Universitas Airlangga, Soetomo Hospital, Surabaya, Indonesia; ${ }^{6}$ Department of Dermatology and Venereology, Faculty of Medicine, Universitas Brawijaya, Malang, Indonesia; ${ }^{7}$ Department of Dermatology and Venereology, Faculty of Medicine,

Universitas Andalas, Padang, Indonesia;

${ }^{8}$ Department of Dermatology and

Venereology, Faculty of Medicine,

Universitas Sam Ratulangi, Prof.

R. D. Kandou Hospital, Manado, Indonesia;

'Department of Dermatology and

Venereology, Faculty of Medicine,

Universitas Udayana, Bali, Indonesia

Correspondence: Hendra Gunawan Department of Dermatology and Venereology, Faculty of Medicine,

Universitas Padjadjaran - Hasan Sadikin

Hospital, Jl. Pasteur 38, Bandung, West

Java, 40I6I, Indonesia

Tel +62 812 2III 1215

Email h.gunawan2016@unpad.ac.id
Background: One of the indicators of achieved leprosy control is lower new cases of leprosy with grade 2 disability (G2D), while zero new pediatric case with G2D is one of the targets of The Global Leprosy Strategy. This study aimed to describe the characteristics of leprosy in children with G2D from seven provincial hospitals in Indonesia, spanning a period of five years. Methods: This was a descriptive and retrospective study with cross-sectional design. Data were obtained from the medical records of leprosy-affected children in seven provincial hospitals in Indonesia between January 2014 and December 2019 using a total sampling method. Data obtained include characteristics of patients, clinical manifestations, and profile of leprosy in children with G2D.

Results: From the 132 data of childhood leprosy retrieved, male (58.33\%), age group of 1314 years $(47.73 \%)$, and borderline tuberculoid leprosy $(34.09 \%)$ comprised the majority of patients. Most of the patients had anesthetic macules as the initial manifestation. The results showed $20(15.15 \%)$ children had G2D. Hands were the most common site affected $(50.00 \%)$, manifested as claw hands, contractures, atrophy of thenar and hypothenar muscles, and pseudomutilation. Foot drop was seen in five (62.50\%) children, and lagophthalmos was seen in one child with leprosy.

Conclusion: This study shows that G2D is observed in $15.15 \%$ Indonesian children with leprosy at the time of diagnosis, which mostly occurs on the hands in the form of claw hands. Foot disabilities were also observed, most commonly as foot drop, while lagophthalmos was present with disabilities in the eyes. Disability due to leprosy in children really exists. The commitment of all health care services and related institutions is needed in order to reduce the incidence of disability due to leprosy in children.

Keywords: children, grade 2 disability, leprosy

\section{Introduction}

Leprosy is an infectious disease that remains a major health problem in developing countries, including Indonesia. ${ }^{1,2}$ Nerve damage that occurs in leprosy can develop into disabilities and create stigma in the society. ${ }^{3}$ In endemic areas, leprosy in children aged less than 15 years is common. The incidence of leprosy in children can be an indicator of the disease's prevalence in the general population and is associated with an active source of transmission. ${ }^{4}$ In 2020, the World Health Organization (WHO) reported 202.185 new leprosy cases registered globally from 127 countries, corresponding to a prevalence of 0.2 per 10,000 , with 14.981 $(7.40 \%)$ cases occurring in children. 
One of the targets of The Global Leprosy Strategy is zero new cases of leprosy in children with grade 2 disability (G2D). According to the 2020 WHO data, there were 10,813 new cases of leprosy with G2D, with $370(3.42 \%)$ of these occurring in children. ${ }^{5}$ Clinical symptoms of leprosy in children are sometimes atypical. ${ }^{4}$ This may cause delay in diagnosis, that can lead to disability and reduced the quality of life. ${ }^{6}$ Epidemiological data regarding the characteristics of disability in children with leprosy are limited. Therefore, this retrospective study aims to describe the characteristics of leprosy in children with G2D from seven provincial hospitals in Indonesia in the course of five years.

\section{Methods}

A cross-sectional descriptive and retrospective study was conducted on medical records of leprosy-affected children in Dermatology and Venereology Clinic of seven provincial hospitals in Indonesia. Data regarding childhood leprosy registered between January 2014 and December 2019 were collected using total sampling method. This study was approved by Hasan Sadikin Hospital Ethics Committee Number LB.02.01/X.6.5/172/ 2020 and conducted in accordance with the latest version of the Declaration of Helsinki. The need for informed consent was waived by the Institutional Review Board as the study was non-interventional and the secondary patient's data provide were sufficiently anonymized. Descriptive analysis was performed on the data of patient characteristics, clinical manifestations, and profile of leprosy in children with G2D including age, sex, leprosy type based on Ridley-Jopling classification, initial symptoms, leprosy reaction, presence of neuritis, bacterial index, the status of treatment, the type of treatment, the degree and type of disability. Disability in leprosy is defined by the WHO grading system: Grade 0-absence of disability (no anesthesia) and no visible damage or deformity on eyes, hands, or feet; Grade 1-loss of protective sensibility on eyes, hands, and feet; Grade 2-presence of deformities or visible damage to the eyes, hands, or feet. $^{7}$

\section{Results}

A total of 132 cases were diagnosed as new cases of leprosy in children in the 5-year study period. Seventyseven $(58.33 \%)$ patients were male and 55 were female $(41.67 \%)$. The highest prevalence occurred in the age group of 13-14 years old (47.73\%). Only one case found in less than 4 years old age group. The distribution of age and gender of leprosy patients in children is presented in Table 1.

Based on the type of leprosy by Ridley-Jopling classification, borderline tuberculoid leprosy comprised the majority of the patients (34.09\%). Most of the patients $(94.42 \%)$ had anesthetic macules as their initial manifestation, while $7.58 \%$ patients had nodules.

Table I Characteristics of Childhood Leprosy Patients

\begin{tabular}{|c|c|c|c|}
\hline \multicolumn{2}{|c|}{ Characteristics } & \multicolumn{2}{|c|}{$\begin{array}{l}\text { Total Childhood Leprosy } \\
\text { Patients }\end{array}$} \\
\hline & & \multirow{3}{*}{$\begin{array}{c}\text { Frequency } \\
\text { (n=132) }\end{array}$} & \multirow{3}{*}{$\begin{array}{c}\begin{array}{c}\text { Percentage } \\
\text { (\%) }\end{array} \\
58.33 \\
41.67\end{array}$} \\
\hline Gender & Male & & \\
\hline & Female & & \\
\hline \multirow[t]{5}{*}{ Age } & $<4$ years old & I & 0.76 \\
\hline & 4-6 years old & 6 & 4.55 \\
\hline & 7-9 years old & 24 & 18.18 \\
\hline & $10-12$ years old & 38 & 28.79 \\
\hline & 13-14 years old & 63 & 47.73 \\
\hline \multirow[t]{5}{*}{ Leprosy type } & TT & 9 & 6.82 \\
\hline & BT & 45 & 34.09 \\
\hline & BB & 25 & 18.94 \\
\hline & $B L$ & 39 & 29.55 \\
\hline & LL & 14 & 10.61 \\
\hline \multirow[t]{2}{*}{$\begin{array}{l}\text { Initial } \\
\text { manifestation }\end{array}$} & $\begin{array}{l}\text { Hypopigmented } \\
\text { macule }\end{array}$ & & 92.42 \\
\hline & Nodule & 10 & 7.58 \\
\hline \multirow[t]{3}{*}{ Reaction } & $R R$ & 27 & 20.45 \\
\hline & ENL & 13 & 9.85 \\
\hline & None & 92 & 69.70 \\
\hline \multirow[t]{2}{*}{ Neuritis } & Yes & 17 & 12.88 \\
\hline & No & 115 & 87.12 \\
\hline \multirow[t]{5}{*}{$\mathrm{BI}$} & Negative & 67 & 50.76 \\
\hline & $1+$ or $2+$ & 20 & 15.15 \\
\hline & $3+$ or $4+$ & 25 & 18.94 \\
\hline & $5+$ or $6+$ & I & 0.76 \\
\hline & Not tested & 19 & 14.39 \\
\hline \multirow{2}{*}{$\begin{array}{l}\text { Therapy } \\
\text { status }\end{array}$} & Ongoing & 37 & 28.03 \\
\hline & RFT & 95 & 71.97 \\
\hline \multirow{2}{*}{$\begin{array}{l}\text { Type of } \\
\text { therapy }\end{array}$} & MDT-PB & 54 & 40.91 \\
\hline & MDT-MB & 78 & 59.09 \\
\hline
\end{tabular}

Abbreviations: TT, tuberculoid; $\mathrm{BT}$, borderline tuberculoid; $\mathrm{BB}$, borderline borderline; $B L$, borderline lepromatous; LL, lepromatous leprosy; RR, reversal reaction; ENL, erythema nodosum leprosum; $\mathrm{Bl}$, bacterial index; RFT, released from treatment; MDT, multidrug therapy; PB, paucibacillary; MB, multibacillary. 
Table 2 Grade and Location of Disability in Childhood Leprosy Patients

\begin{tabular}{|l|l|c|c|}
\hline \multicolumn{2}{|l|}{ Characteristics } & \multicolumn{2}{c|}{ Total Cases } \\
\cline { 3 - 4 } \multicolumn{2}{|c|}{ Frequency (n=132) } & (\%) \\
\hline Grade of disability & 0 & 98 & 74.24 \\
& 1 & 14 & 10.61 \\
& 2 & 20 & 15.15 \\
\hline Location of disability & \multicolumn{2}{|c|}{} \\
\hline Eyes & Grade 0 & 130 & 98.48 \\
& Grade I & 0 & 0 \\
& Grade 2 & 2 & 1.52 \\
\hline Hand & Grade 0 & 120 & 90.90 \\
& Grade I & 2 & 1.52 \\
& Grade 2 & 10 & 7.58 \\
\hline \multirow{2}{*}{ Foot } & Grade 0 & 123 & 93.18 \\
& Grade I & 1 & 0.75 \\
& Grade 2 & 8 & 6.07 \\
\hline
\end{tabular}

Twenty-seven patients (20.45\%) developed a reversal reaction and $13(9.85 \%)$ patients had history of erythema nodosum leprosum (ENL). Neuritis was found in 17 patients (12.88\%). The percentage of cases was slightly higher on negative bacterial index (BI) $(50.76 \%)$ than on positive BI $(34.85 \%)$, while $14.39 \%$ of the patients were not tested. On treatment status, most patients were eventually released from treatment (71.97\%). The majority of patients $(59.09 \%)$ received multidrug therapy for multibacillary leprosy (MDT-MB). Clinical characteristics of leprosy patients in children are summarized in Table 1.

A total of $34(25.76 \%)$ children with leprosy had disabilities, with 14 (10.61\%) being grade 1 disability (G1D) and 20 (15.15\%) being G2D. The grade of disability in children is presented in Table 2. Among the children with G2D, hand disabilities $(50.00 \%)$ were the most common. The location of disability in childhood leprosy patient is presented in Table 2. Four $(40.00 \%)$ patients had claw hands, three $(30.00 \%)$ patients showed contractures, two $(20.00 \%)$ patients had atrophy of the thenar and hypothenar muscles, and one (10.00\%) patient had pseudomutilation. Among eight (6.07\%) patients with foot disabilities, it was noted that five $(62.50 \%)$ patients had foot drop and three $(37.50 \%)$ patients had ulcer. Eye disability, manifesting as lagophthalmos, was present in one patient. The type of disability is summarized in Table 3.
Table 3 Types of Grade 2 Disability of the Hand, Foot, and Eye in Childhood Leprosy Patients

\begin{tabular}{|l|c|c|}
\hline Characteristics & Frequency (n) & Percentage (\%) \\
\hline $\begin{array}{l}\text { Grade 2 Disability of the } \\
\text { Hand (n=10) }\end{array}$ & & \\
$\quad$ Claw hand & 4 & 30.00 \\
Contracture & 5 & 40.00 \\
Atrophy of thenar and & 2 & 20.00 \\
hypothenar muscle & & 10.00 \\
Pseudomutilation & 1 & 0 \\
Ulcer & 0 & \\
\hline Grade 2 Disability of the & & 62.50 \\
Foot (n=8) & 5 & 67.50 \\
Foot drop & 3 & 0 \\
Ulcer & 0 & 0 \\
Contracture & 0 & 0 \\
Atrophy of the thenar and & & 50 \\
hypothenar muscle & 0 & \\
Pseudomutilation & & \\
\hline Grade 2 Disability of the & & \\
Eyes (n=2) & & \\
Lagophthalmos & & \\
\hline
\end{tabular}

\section{Discussion}

According to the 2020 WHO leprosy data, there were 17,439 new cases in Indonesia, with 2009 cases occurred in children. ${ }^{5}$ Our study was conducted from 2014 to 2019 and included 132 new childhood cases of leprosy. The incidence of leprosy in children can be an indicator of the disease's prevalence in the general population and is associated with the existence of an active source of transmission. Childhood leprosy is usually transmitted from family contacts, indicating the high disease transmissibility in the community. ${ }^{4}$ Our study showed that the highest proportion of cases were found in the age group of 13-14 years old $(47.73 \%)$, followed by $10-12$ years old $(28.79 \%)$, and $7-9$ years old $(18.18 \%)$. This result was similar to a study by Darlong et al in India, which showed the most prevalent case of leprosy in children occurred in the age group of 13-15 years old. ${ }^{6}$ In a study by Rodrigues et al in Brazil, the highest proportion of cases occurred among those aged 8-14 years old. ${ }^{8}$ In another study by Zia et al in Pakistan, the most affected age group was 11-14 years old. ${ }^{9}$ This distribution shows that leprosy is more common in adolescents (older children), which may be due to the disease's relatively long incubation period. ${ }^{10}$ According to data from the Ministry of Health of the Republic of Indonesia in 2018, new cases of leprosy in 
Indonesia were more prevalent in males (9,872 cases) compared to females $(6,048$ cases $){ }^{2}$ In the current study, leprosy was also most commonly found in males than in females. Similar results were found in other studies by Darlong et al in India, Santos et al in Brazil, Ramos et al in Ethiopia, and Jha et al in Nepal. ${ }^{6,11-13}$ This might be due to involved environmental and socio-cultural factors such as greater exposure from more outdoor activities in males. ${ }^{10}$ Cultural factor may also play a role, where parents of male children were less likely to seek medical attention compared to parents of female children. ${ }^{4}$

Our study showed that borderline tuberculoid leprosy (34.09\%) was the most common type of leprosy seen in children. Similiar result was found in a study by Kumaravel et al. That reported BT as the most common leprosy type in children $(58.70 \%){ }^{10}$ The study by Ramos et al reported that the most common type of leprosy in patients aged $\leq 18$ years was the MB type. ${ }^{12}$ Although the majority of leprosy in children under 15 years of age in India were paucibacillary (PB), a study by Pinto et al found that $\mathrm{MB}$ cases were predominant. ${ }^{14}$ The high number of children with MB leprosy may be related to the delay in reporting, ${ }^{15}$ widespread nerve damage, and extensive nerve involvement. ${ }^{13}$

In the current study, the majority of childhood leprosy patients had early symptoms of hypopigmented anesthetic macules on the skin $(92.42 \%)$, while 10 patients $(7.58 \%)$ had nodules as their early symptom. This was similar with other studies by Zia et $\mathrm{al}^{9}$ in Pakistan, Narang et $\mathrm{al}^{16}$ in India, and Das et $\mathrm{al}^{17}$ in India, who found that the most common initial symptom in childhood leprosy patients was anesthetic hypopigmented macules on exposed body parts, such as the face, arms, and lower limbs.

Leprosy reactions are a major cause of nerve damage and morbidity in leprosy patients. ${ }^{12}$ There are two types of leprosy reaction: type 1 reaction (reversal reaction) and type 2 reaction (ENL). ${ }^{12}$ In this study, leprosy reaction occurred as type 1 in $14(10.61 \%)$ patients and type 2 in 20 $(15.15 \%)$ patients. The clinical manifestation of leprosy depends on the interaction between $M$. leprae and the immune response. ${ }^{3}$ The results of several other studies showed that the frequency of leprosy reactions in children tends to be low. ${ }^{13,15,16}$ Cases of leprosy reaction in children range from $3.1 \%$ to $33.9 \%$ compared to adults, which can be as high as $50 \% .{ }^{14}$ In this study, neuritis was found in $17(12.88 \%)$ patients. Govindharaj et al in their study showed that neuritis in pediatric leprosy was relatively uncommon $(18.5 \%){ }^{15}$ The finding of leprosy reaction and/or neuritis in this study revealed the severity of the cases and may cause neural damage and deformities. This condition should be identified and treated immediately and adequately to prevent disabilities.

The majority of patients in the current study were released from therapy (71.97\%). This was similar to another study by Govindharaj et al, ${ }^{15}$ who reported that the majority of leprosy patients observed in that study completed their therapy. This data is crucial to the effort of preventing disabilities in pediatric leprosy patients and also for the attention of health planners to the need to develop health system and special actions for childhood in leprosy.

Children with disability have many difficulties in education, social life, and daily activities. ${ }^{16}$ In this study, G2D was found in 20 cases. From the results of a study in India, it was known that in children aged less than 14 years, a disability from leprosy was uncommon. G1D was only found in 3\% of cases, and G2D was found in 5\% cases. ${ }^{18}$ In the current study, G2D of the hands occurred in $10(50.00 \%)$ cases, in the form of claw hands $(40.00 \%)$, contractures $(30.00 \%)$, atrophy of the thenar and hypothenar muscles (20.00\%), and pseudomutilation (10.00\%). G2D of the foot occurred in 8 patients, which manifested as foot drop $(62.50 \%)$ and ulcer $(37.50 \%)$. Disabilities of the eyes occurred as lagophthalmos in one patient. Kumaravel et $\mathrm{al}^{10}$ in their study found that the most common disability in pediatric leprosy cases was claw hand, followed by tropic ulcers, foot drop, and wrist drop. The high incidence of claw hand is due to the fact that the ulnar nerve is the most commonly affected peripheral nerve. Paralytic deformities are caused by the destruction of motor nerve fibers innervating the intrinsic and motor muscles. Overall, disabilities in childhood leprosy were often caused by ignorance of the child's family, lack of cooperation, and delay in diagnosis and therapy, resulting in disease progression that may lead to disability. ${ }^{6}$

\section{Conclusion}

This study shows that G2D is observed in $15.15 \%$ Indonesian children with leprosy at the time of diagnosis, which mostly occurs on the hands in the form of claw hands. Foot disabilities were also observed, most commonly as foot drop, while lagophthalmos was present with disabilities in the eyes. Disability due to leprosy in children really exists, indicating active transmission and delays in diagnosis and treatment of leprosy. The commitment of all health care services and related institutions is needed in order to reduce the incidence of disability due to leprosy in children. 


\section{Acknowledgments}

The authors would like to thank the Indonesian Leprosy Study Group, the Indonesian Society of Dermatology and Venereology, and the Indonesian College of Dermatology and Venereology for providing meeting, editorial, and general administrative support.

\section{Funding}

The authors declare that this study has received no financial support.

\section{Disclosure}

The authors have no conflicts of interest for this work to declare.

\section{References}

1. Salgado CG, de Brito AC, Salgado UI, Spencer JS. Leprosy. In: Kang S, Amagai M, Bruckner AL, et al., editors. Fitzpatrick's Dermatology in General Medicine. 9th ed. New York: McGraw-Hill; 2019:2892-2919.

2. Ministry of Health of the Republic of Indonesia. [Infodatin: eliminate stigma and discrimination against leprosy]; 2018. Available from: https://pusdatin.kemkes.go.id.Indonesian.

3. Lugão HB, Frade MA, Mazzer N, Foss NT, Nogueira-Barbosa MH. Leprosy with ulnar nerve abscess: ultrasound findings in a child. Skeletal Radiol. 2017;46(1):137-140. doi:10.1007/s00256-016-2517-1

4. Patil RR. Determinants of leprosy with special focus on children: a socio-epidemiologic perspective. J Eur Acad Dermatol Venereol. 2013;2(2):5-9.

5. World Health Organization. Global Leprosy (Hansen's Disease) update, 2018: time to step up prevention initiatives. Wkly Epidemiol Rec. 2020;95(36):417-438.

6. Darlong JO, Govindharaj P, Darlong F, Mahato N. A study of untreated leprosy affected children reporting with Grade 2 disability at a referral centre in West Bengal, India. Leprosy Rev. 2017;88 (3):298-305. doi:10.47276/lr.88.3.298
7. World Health Organization. Global Strategy for further reducing the leprosy burden and sustaining leprosy control activities (2006-2010): operational guidelines. WHO; 2006.

8. Rodrigues TS, Gomes LC, Cortela DC, Silva EA, Silva CA, Ferreira SM. Factors associated with leprosy in children contacts of notified adults in an endemic region of Midwest Brazil. J Pediatr (Rio J). 2020;96(5):593-599. doi:10.1016/j.jped.2019.04.004

9. Zia M, Anwar MI, Iqbal M. Childhood leprosy: a retrospective descriptive study from Pakistan. J Pak Assoc Dermatol. 2019;29 (1):30-34.

10. Kumaravel S, Murugan S, Fathima S, Anandan H. Clinical presentation and histopathology of childhood leprosy. Int J STEM Educ. 2017;4(11):167-169.

11. Santos VS, Santos LC, Lôbo LV, Lemos LM, Gurgel RQ, Cuevas LE. Leprosy and disability in children younger than 15 years in an endemic area of northeast Brazil. Pediatr Infect Dis J. 2015;34(3): e44-7. doi:10.1097/INF.0000000000000592

12. Ramos JM, Ortiz-Martínez S, Lemma D, et al. Epidemiological and clinical characteristics of children and adolescents with leprosy admitted over 16 years at a rural hospital in Ethiopia: a retrospective analysis. J Trop Pediatr. 2017;64(3):195-201. doi:10.1093/tropej/fmx048

13. Jha R, Marahatta S. Profiles of pediatric leprosy: a report from a University Hospital of Nepal in the post-elimination era. Am J Trop Med Hyg. 2021;104(1):219-222. doi:10.4269/ajtmh.20-1135

14. Pinto AC, Wachholz PA, Silva GV, Masuda PY. Profile of leprosy in children under 15 years of age monitored in a Brazilian referral center (2004-2012). An Bras Dermatol. 2017;92(4):580-582. doi:10.1590/abd1806-4841.20175676

15. Govindharaj P, Darlong J, John AS, Mani S. Children and adolescents' attitude towards having leprosy in a high endemic district of India. Lepr Rev. 2016;87:42-52. doi:10.47276/1r.87.1.42

16. Narang T, Kumar B. Leprosy in children. IJPD. 2019;20(1):12.

17. Das L, Meher BK, Das NB, Pradhan DD, Pradeep S, Mohanty J. A Clinco-Bacteriological Study of Leprosy in Paediatric Age Group. Adv Infect Dis. 2013;3(04):269. doi:10.4236/aid.2013. 34041

18. Ramasamy S, Kumar A, Govindharaj P. Screening household contacts of children diagnosed with leprosy in a tertiary referral centre, Chhattisgarh State, India. Lepr Rev. 2018;89(2):117-123. doi:10. 47276/lr.89.2.117
Clinical, Cosmetic and Investigational Dermatology

\section{Publish your work in this journal}

Clinical, Cosmetic and Investigational Dermatology is an international, peer-reviewed, open access, online journal that focuses on the latest clinical and experimental research in all aspects of skin disease and cosmetic interventions. This journal is indexed on CAS.

\section{Dovepress}

The manuscript management system is completely online and includes a very quick and fair peer-review system, which is all easy to use. Visit http://www.dovepress.com/testimonials.php to read real quotes from published authors. 